\title{
Synthesis, physicochemical and biological characterization of $\mathrm{Ni}$ (II) complex with imidazole-4-acetate anion as new antifungal agent
}

\author{
KATARZYNA GAŁCZYŃSKA ${ }^{\mathrm{a}}$, KRYSTYNA KURDZIEL ${ }^{\mathrm{b}}, \mathrm{KAROL} \mathrm{CIEPLUCH}^{\mathrm{a}}$, \\ JAROSŁAW RACHUNA ${ }^{\mathrm{a}}$, MAGDALENA KOWALSKA ${ }^{\mathrm{a}}$, ŁUKASZ MADEJ ${ }^{\mathrm{c}}$, \\ ANETA WĘGIEREK-CIUK ${ }^{\mathrm{d}}$, ANNA LANKOFF $^{\mathrm{d}, \mathrm{e}}$ and MICHAŁ ARABSKI ${ }^{\mathrm{a}, *}$ (B) \\ ${ }^{a}$ Department of Biochemistry and Genetics, Institute of Biology, Jan Kochanowski University, Świętokrzyska \\ 15, 25-406 Kielce, Poland \\ ${ }^{\mathrm{b}}$ Institute of Chemistry, Jan Kochanowski University, Świętokrzyska 15G, 25-406 Kielce, Poland \\ ${ }^{\mathrm{c}}$ Holycross Cancer Center, Artwińskiego 3, 25-734 Kielce, Poland \\ ${ }^{\mathrm{d} D}$ Department of Radiobiology and Immunology, Jan Kochanowski University, Świętokrzyska 15, 25-406 Kielce, \\ Poland \\ ${ }^{\mathrm{e}}$ Center for Radiobiology and Biological Dosimetry, Institute of Nuclear Chemistry and Technology, Dorodna \\ 16, 03-195 Warsaw, Poland \\ E-mail: arabski@ujk.edu.pl
}

MS received 15 July 2018; revised 5 October 2018; accepted 18 October 2018; published online 30 November 2018

\begin{abstract}
The neutral mononuclear nickel(II) complex with an imidazole-4-acetate anion (iaa), having the formula [Ni(iaa) $\left.)_{2}\left(\mathrm{H}_{2} \mathrm{O}\right)_{2}\right] \cdot \mathrm{H}_{2} \mathrm{O}$, was characterized by single-crystal X-ray diffraction, IR, farIR, UV-Vis-NIR spectra and magnetic measurements. The imidazole-4-acetate anion in this complex is a chelating ligand where an azomethine nitrogen atom of the imidazole ring and carboxylate oxygen atoms are donor atoms. The immediate environment of the central nickel(II) ion is described by distorted cis-octahedron ( $\mathrm{NiN}_{2} \mathrm{O}_{4}$ chromophore). The analysis of biological properties of $\left[\mathrm{Ni}(\mathrm{iaa})_{2}\left(\mathrm{H}_{2} \mathrm{O}\right)_{2}\right] \cdot \mathrm{H}_{2} \mathrm{O}$ complex has shown that this complex at non-cytotoxic concentration against normal human BEAS-2B cell has antifungal properties. The biophysical studies have shown that of $\left[\left[\mathrm{Ni}(\mathrm{iaa})_{2}\left(\mathrm{H}_{2} \mathrm{O}\right)_{2}\right] \cdot \mathrm{H}_{2} \mathrm{O}\right]$ interacts with DNA without degradation and with $\mathrm{BSA}$ as a model protein.
\end{abstract}

Keywords. Nickel(II) complex; imidazole-4-acetate anion; antifungal; cytotoxicity.

\section{Introduction}

The biological activities of nickel complexes in eukaryotic and prokaryotic cells are well documented. ${ }^{1-4}$ Generally, these mechanisms are linked with binding to DNA by intercalation and/or electrostatic interactions as well as with effect on the catalytic activity of proteins leading to block of biosynthesis processes on a cellular level. It seems to be important that the biological properties of $\mathrm{Ni}$ (II) complexes depend on physical and chemical properties determined both by metal and ligands. For example, the molecular mechanisms of nickel(II) toxicity are associated directly with the generation of reactive oxygen species (ROS) which promote oxidative modification of nitrogenous bases and, indirectly, with the induction of DNA strand breaks, AP sites (apurinic/apyrimidinic) and/or sister chromatid exchanges. ${ }^{5-7}$ However, the presence of imidazole-4acetate anion in metal complexes may promote effective transport of these molecules by changing the permeability of the cell membrane and makes more intense bactericidal and fungicidal effects. Moreover, metal complexes with imidazole in contrast to metal ions alone should reduce the redox potential in the environment of free radical reactions and decrease the high cytotoxicity of metals ions. Nickel(II) tends to form complexes with imidazole moieties of proteins in natural conditions and interfere with their biological activities. Nickel(II) ions

\footnotetext{
*For correspondence

Electronic supplementary material: The online version of this article (https://doi.org/10.1007/s12039-018-1574-5) contains supplementary material, which is available to authorized users.
} 
might replace the essential metal of metalloproteins, binds to catalytic residues of non-metalloenzymes, binds outside the catalytic site of an enzyme to inhibit allosterically and indirectly causes oxidative stress. The application of nickel(II) ions alone as antimicrobial agents is problematic, taking their cytotoxicity against human cells as a side effect into consideration. So, in this study, a new approach based on nickel(II) ions in the complex acting in the human body as an antimicrobial agent is presented. The aim of our study was to synthesize and characterize the nickel(II) complex with imidazole-4 acetic acid, a naturally occurring metabolite in the brain, and to examine the antimicrobial properties of $\left[\mathrm{Ni}(\mathrm{iaa})_{2}\left(\mathrm{H}_{2} \mathrm{O}\right)_{2}\right] \cdot \mathrm{H}_{2} \mathrm{O}$ at non-cytotoxic concentration against human cells. Physicochemical characterization of synthesized nickel(II) complex included the singlecrystal X-ray diffraction, IR, farIR, UV-Vis-NIR spectra and magnetic measurements. Cytotoxicity was examined by the MTT test and Annexin/IP assay in normal human BEAS-2B line used as a model of eukaryotic cells. The bactericidal and fungicidal effects were tested using microbiological test. The interactions of synthesized nickel(II) complex with DNA and proteins were characterized. In this part of the study, the novel application of the PCR-HRM method is presented for the first time.

\section{Experimental}

\subsection{Materials and physical measurements}

All the chemicals were purchased from Sigma Aldrich Co.: nickel(II) nitrate, imidazole-4-acetate sodium salt, fish sperm DNA, and ethidium bromide (EB). Bacterial strains: Escherichia coli ATCC 8739, Staphylococcus aureus ATCC 6538P, Pseudomonas aeruginosa ATCC 15692 PAO1, Candida albicans ATTC 10231 and SC5314 strains originated from Department of Biochemistry and Genetics, Jan Kochano wski University (Kielce, Poland). The normal human bron chial epithelium BEAS-2B cells (ATCC ${ }^{\circledR}$ CRL-9609'TM) were provided by American Tissue Cell Collection. BEAS-2B cells were cultured in the LHC9 medium at $37^{\circ} \mathrm{C}$ in a humidified $5 \% \mathrm{CO}_{2}$ atmosphere.

Elemental analyses were conducted on a Model 240 Perkin Elmer CHN Analyzer. The IR spectra were recorded on a Perkin Elmer 180 (spectral range $50-4000 \mathrm{~cm}^{-1}$ ) spectrophotometer in Nujol and in $\mathrm{KBr}$ pellets. The far-IR spectra were obtained in Nujol mulls sandwiched between polyethylene plates. The electronic spectra $\left(5000-30000 \mathrm{~cm}^{-1}\right.$ ) were recorded on a Cary 5 UV-VIS-NIR spectrophotometer in Nujol mulls. Magnetic susceptibility data were measured at room temperature with an MSB-MKI Instrument (Sherwood Scientific Ltd) with $\mathrm{Co}\left[\mathrm{Hg}(\mathrm{SCN})_{4}\right]$ as standard and corrected for diamagnetism according to
Pascal's constants. The conductivity measurements were carried out with an inaLab Con 720 Conductivity Meter. The absorbance spectra were measured on a Hitachi U 2900 spectrophotometer. The fluorescence emission spectra were measured on Hitachi F 700 spectrofluorometer. The fluorescence spectra were measured using the excitation wavelength of $300 \mathrm{~nm}$, the emission range was set between 520 and $750 \mathrm{~nm}$. The PCR-HRM analysis was conducted in a LightCycler 480 II (Hoffman-LaRoche, Switzerland) using LightCycler 480 Gene Scanning Software (version 1.5) for the curve analysis.

\subsection{Synthesis of $\left[\mathrm{Ni}(\mathrm{iaa})_{2}\left(\mathrm{H}_{2} \mathrm{O}\right)_{2}\right] \cdot \mathrm{H}_{2} \mathrm{O}$}

The complex was obtained from aqueous solutions containing nickel nitrate (V) and imidazole-4-acetate sodium salt $\left(\mathrm{Na}\right.$ (iaa) $\left.\cdot \mathrm{H}_{2} \mathrm{O}\right)$ in the molar ratio 1:3. A solution of $\mathrm{Ni}\left(\mathrm{NO}_{3}\right)_{2} \cdot 6 \mathrm{H}_{2} \mathrm{O}(1 \mathrm{mmol})$ in $50 \mathrm{~cm}^{3}$ of distilled water was added dropwise to a stirred solution of $\mathrm{Na}(\mathrm{iaa}) \cdot \mathrm{H}_{2} \mathrm{O}$ in $50 \mathrm{~cm}^{3}$ of water. The solution was left to stand at room temperature for seven days. The green crystals of definite stoichiometry, suitable for X-ray analysis, were obtained. Yield: $72 \%$ based on Ni. Complex [Ni(iaa) $\left.)_{2}\left(\mathrm{H}_{2} \mathrm{O}\right)_{2}\right] \cdot \mathrm{H}_{2} \mathrm{O}: \mathrm{C}_{10} \mathrm{H}_{16} \mathrm{~N}_{4} \mathrm{NiO}_{7}$ : Anal. Found: C, 33.2; H, 4.6; N, 15.3\% Calc. C,33.09; H,4.44; $\mathrm{N}, 15.43 \%$ IR $\left(\mathrm{cm}^{-1}\right): v_{\mathrm{HOH}} 3560, v_{\mathrm{asCOO}}-1580, v_{\mathrm{sCOO}}$ 1404, $\delta_{\mathrm{HOH}} 1650$ : Conductivity $\left(\Lambda \mathrm{o}, \mathrm{ohm}^{-1} \mathrm{~cm}^{2} \mathrm{~mol}^{-1}\right)$ in $\mathrm{H}_{2} \mathrm{O}: 37.55$.

\subsection{Crystal data of $\left[\mathrm{Ni}(\mathrm{iaa})_{2}\left(\mathrm{H}_{2} \mathrm{O}\right)_{2}\right] \cdot \mathrm{H}_{2} \mathrm{O}$}

X-ray measurements were performed on a Kuma KM4CCD diffractometer. The structures were solved by direct methods using the SHELX $-97^{8}$ and refined by the full-matrix leastsquares method using the SHELXL- $97^{9}$ programme. The $\mathrm{H}$ atoms were included from the geometry of molecules and were not refined. Crystal data and details of data collection and refinement procedure are collected in Table 1.

\subsection{Interactions of $\left[\mathrm{Ni}(\mathrm{iaa})_{2}\left(\mathrm{H}_{2} \mathrm{O}\right)_{2}\right] \cdot \mathrm{H}_{2} \mathrm{O}$ with $\mathrm{DNA}$}

The interactions of $\left[\left[\mathrm{Ni}(\mathrm{iaa})_{2}\left(\mathrm{H}_{2} \mathrm{O}\right)_{2}\right] \cdot \mathrm{H}_{2} \mathrm{O}\right]$ complex with DNA were measured by the absorption spectral studies, competitive binding fluorescence measurements and polymerase chain reaction (PCR) with high resolution melting (HRM).

2.4a Absorption spectral studies of [Ni(iaa $\left.)_{2}\left(\mathrm{H}_{2} \mathrm{O}\right)_{2}\right]$. $\mathrm{H}_{2} \mathrm{O}$ complex: Fish sperm DNA was used as the standard probe of DNA sample. All experiments were carried out in Tris- $\mathrm{HCl}$ buffer at $\mathrm{pH}$ 7.2. The solution of DNA was stored at $4{ }^{\circ} \mathrm{C}$ and used for no longer than a week. The DNA concentration was determined by a UV spectrophotometer, using the molar absorption coefficient $6600 \mathrm{M}^{-1} \mathrm{~cm}^{-1}$ at $258 \mathrm{~nm} .{ }^{10}$ A solution gave the ratio of UV absorbance at 260 and $280 \mathrm{~nm}\left(\mathrm{~A}_{260} / \mathrm{A}_{280}\right)$ equal to 1.87 , indicating that the DNA was sufficiently free of protein. ${ }^{11}$ The absorbance titrations were performed in a fixed concentration of metal complexes $\left(75 \mathrm{mM}\right.$ for $\left.\left[\mathrm{Ni}(\mathrm{iaa})_{2}\left(\mathrm{H}_{2} \mathrm{O}\right)_{2}\right] \mathrm{H}_{2} \mathrm{O}\right)$ while gradually increasing the DNA concentration (from 0 to $220 \mathrm{mM}$ ). To obtain 
Table 1. Crystal data and structure refinement for $\left[\mathrm{Ni}(\mathrm{iaa})_{2}\left(\mathrm{H}_{2} \mathrm{O}\right)_{2}\right] \mathrm{H}_{2} \mathrm{O}$.

\begin{tabular}{|c|c|}
\hline Empirical formula & $\mathrm{C}_{10} \mathrm{H}_{16} \mathrm{~N}_{4} \mathrm{Ni} \mathrm{O}_{7}$ \\
\hline Formula weight & 362.98 \\
\hline Temperature (K) & $100(1)$ \\
\hline Wavelength $(\AA)$ & 0.71073 \\
\hline Crystal system & Monoclinic \\
\hline Space group & $\mathrm{P} 2(1) / \mathrm{c}$ \\
\hline$a(\AA)$ & $9.594(2)$ \\
\hline$b(\AA)$ & $7.436(2)$ \\
\hline$c(\AA)$ & $19.322(3)$ \\
\hline$\beta\left({ }^{\circ}\right)$ & $97.32(2)$ \\
\hline Volume $\left(\AA^{3}\right)$ & $1367.2(3)$ \\
\hline $\mathrm{Z}$ & 4 \\
\hline Density (calculated) $\left(\mathrm{mg} / \mathrm{m}^{3}\right)$ & 1.763 \\
\hline Absorption coefficient $\left(\mathrm{mm}^{-1}\right)$ & 1.463 \\
\hline $\mathrm{F}(000)$ & 752 \\
\hline Crystal size (mm) & $0.15 \times 0.15 \times 0.18$ \\
\hline $2 \theta$ range $\left(^{\circ}\right)$ & 3.47 to 28.25 \\
\hline Index ranges & $-12 \leq \mathrm{h} \leq 12,-9 \leq \mathrm{k} \leq 9,-25 \leq 1 \leq 23$ \\
\hline Reflections collected/unique & $8959 / 3165[\mathrm{R}($ int $)=0.0392]$ \\
\hline Data $[I>2 \sigma(I)] /$ parameters & $2751 / 263$ \\
\hline Goodness-of-fit on $\mathrm{F}^{2}$ & 1.095 \\
\hline Final $R$ indices $[I>2 \sigma(I)]$ & $\mathrm{R} 1=0.0282, w \mathrm{w} 2=0.0629$ \\
\hline $\mathrm{R}$ indices (all data) & $\mathrm{R} 1=0.0364, w \mathrm{R} 2=0.0659$ \\
\hline Largest difference peak and hole $\left(\mathrm{e} . \AA^{-3}\right)$ & 0.363 and -0.596 \\
\hline
\end{tabular}

the absorption spectra, the required amount of DNA was added to both complex solutions and the reference solution to eliminate the absorbance of DNA itself. Each sample solution was allowed to equilibrate $10 \mathrm{~min}$ before the spectra was recorded. Using the absorption titration data, the binding constant $\mathrm{K}_{\mathrm{b}}$ was determined according to the equation ${ }^{12,13}$ : $[\mathrm{DNA}] /\left(\varepsilon_{\mathrm{a}}-\varepsilon_{\mathrm{f}}\right)=[\mathrm{DNA}] /\left(\varepsilon_{\mathrm{b}}-\varepsilon_{\mathrm{f}}\right)+1 / \mathrm{K}_{\mathrm{b}}\left(\varepsilon_{\mathrm{b}}-\varepsilon_{\mathrm{f}}\right)$ where; [DNA] is the concentration of DNA in the base pairs, $\varepsilon_{\mathrm{a}}$ corresponds to the extinction coefficient observed $\left(\mathrm{A}_{\mathrm{obs}} /[\mathrm{M}]\right)$, $\varepsilon_{\mathrm{f}}$ corresponds to the coefficient of free compound, $\varepsilon_{\mathrm{b}}$ is the extinction coefficient of the compound fully bound to DNA and $K_{b}$ is the intrinsic binding constant. $K_{b}$ values were given by the ratio of the slope to intercept in the plot of [DNA] $/\left(\varepsilon_{\mathrm{a}}-\varepsilon_{\mathrm{f}}\right) v s$. [DNA].

\section{4b Fluorescence measurements of competitive} binding: The relative binding of $\left[\mathrm{Ni}(\mathrm{iaa})_{2}\left(\mathrm{H}_{2} \mathrm{O}\right)_{2}\right] \cdot \mathrm{H}_{2} \mathrm{O}$ to DNA was determined with an ethidium bromide-bound DNA solution in Tris- $\mathrm{HCl} / \mathrm{NaCl}$ buffer, $\mathrm{pH}$ 7.2. The experiments were carried out by adding a certain amount of a $\mathrm{Ni}$ (II) complex solution step by step into the EB-DNA solution $(5.5 \mu \mathrm{M}$ $\mathrm{EB}$ and $342 \mu \mathrm{M}$ DNA). Before the emission spectra were recorded, the solutions were incubated at room temperature for $20 \mathrm{~min}$ in order to fully react. The spectra were analyzed according to the classical Stern-Volmer equation ${ }^{14,15}$ :

$\mathrm{I}_{0} / I=1+\mathrm{K}_{\mathrm{sv}}[Q]$

where $I_{0}$ and I are the fluorescence intensities at $599 \mathrm{~nm}$ in the absence and presence of the quencher, respectively, $\mathrm{K}_{\mathrm{SV}}$ is the linear Stern-Volmer quenching constant, and [Q] is the concentration of the $\left[\mathrm{Ni}(\mathrm{iaa})_{2}\left(\mathrm{H}_{2} \mathrm{O}\right)_{2}\right] \cdot \mathrm{H}_{2} \mathrm{O}$ complex.

2.4c PCR-HRM: PCR-HRM was performed with the use of SYBR Green saturation dye (LightCycler 480 SYBR Green I Master, Hoffman-LaRoche, Switzerland). Sequences of primers used in the reaction: forward $5^{\prime}$ - GCT GTT TTC AAA GTG ATT TTG GGA GAA $-3^{\prime}$ and reverse 5'- CAC TCA TTT GTT TCA AAT TGG AATG $-3^{\prime}$ for the gene $t$ tr 4 with an amplicon length of $147 \mathrm{bp}$. PCR reaction mix was contained DNA isolated from human whole blood, $0.5 \mu \mathrm{M}$ each of primers, $5 \mu \mathrm{L}$ of Master Mix and PCR-grade water adjusted to a total volume of $10 \mu \mathrm{L}$. PCR amplification was performed with initial denaturation at $95{ }^{\circ} \mathrm{C}$ for $5 \mathrm{~min}$ followed by 40 cycles at $95{ }^{\circ} \mathrm{C}$ for $10 \mathrm{~s}$ and $60{ }^{\circ} \mathrm{C}$ for $50 \mathrm{~s}$, acquiring at $72{ }^{\circ} \mathrm{C}$ for $30 \mathrm{~s}$. After amplification, [Ni(iaa) $\left.)_{2}\left(\mathrm{H}_{2} \mathrm{O}\right)_{2}\right] \mathrm{H}_{2} \mathrm{O}$ or nickel chloride were added to the prepared DNA amplicon and incubated for $1 \mathrm{~h}$ at $37^{\circ} \mathrm{C}$ and subsequently followed by a melting curve HRM protocol. HRM ramps were generated by acquiring fluorescence data at the temperature ramp of $37^{\circ} \mathrm{C}$ to $95^{\circ} \mathrm{C}$ at $0.1{ }^{\circ} \mathrm{C}$ intervals.

\subsection{Interactions of $\left[\mathrm{Ni}(\mathrm{iaa})_{2}\left(\mathrm{H}_{2} \mathrm{O}\right)_{2}\right] \cdot \mathrm{H}_{2} \mathrm{O}$ with proteins}

The interaction between $\left[\mathrm{Ni}(\mathrm{iaa})_{2}\left(\mathrm{H}_{2} \mathrm{O}\right)_{2}\right] \cdot \mathrm{H}_{2} \mathrm{O}$ and Bovine Serum Albumin (BSA) was tested by the spectrofluorimetric method. The fluorescence quenching of BSA tryptophan residue in presence of metal complexes was analyzed. Fluorescence was measured with Microplate 
Reader TECAN Infinite $200 \mathrm{PRO}$ at $22{ }^{\circ} \mathrm{C}$. The excitation wavelength of $290 \mathrm{~nm}$ was used and the emission spectra were recorded from 300 to $440 \mathrm{~nm}$. Quenching of tryptophan fluorescence was measured at an emission wavelength of $350 \mathrm{~nm}$. Protein was dissolved in $10 \mathrm{mmol} / \mathrm{L}$ sodium phosphate buffer ( $\mathrm{pH} 7.4)$ at $2.5 \mu \mathrm{M}$. Next, increasing concentrations of $\left[\mathrm{Ni}(\mathrm{iaa})_{2}\left(\mathrm{H}_{2} \mathrm{O}\right)_{2}\right] \cdot \mathrm{H}_{2} \mathrm{O}$ were added and fluorescence spectra were recorded.

\subsection{Analysis of cytotoxicity of [Ni(iaa $\left.)_{2}\left(\mathrm{H}_{2} \mathrm{O}\right)_{2}\right]$. $\mathrm{H}_{2} \mathrm{O}$ and its components in eukaryotic cells}

The exponentially growing BEAS-2B cells were treated with $\left[\mathrm{Ni}(\mathrm{iaa})_{2}\left(\mathrm{H}_{2} \mathrm{O}\right)_{2}\right] \cdot \mathrm{H}_{2} \mathrm{O}$, nickel or ligand alone at the range of concentrations $15-500 \mu \mathrm{M}$ for $48 \mathrm{~h}$. Analysis of apoptotic and necrotic cell death was carried out according to manufacturer instructions using Annexin V-FITC apoptosis detection Kit I (BD Pharmingen, USA). Briefly, cells were washed twice with cold PBS and then resuspended in a $1 \times$ binding buffer at a concentration of $1 \times 10^{6}$ cells $/ \mathrm{ml}$. An aliquot of $125 \mu \mathrm{L}$ of the cell suspension was incubated with $5 \mu \mathrm{l}$ of annexin V-FITC and $5 \mu \mathrm{L}$ of propidium iodide (PI) at room temperature for $15 \mathrm{~min}$. in the dark. The cells were resuspended in $400 \mu \mathrm{L}$ of $1 \times$ binding buffer. The fluorescence was determined using a Becton Dickinson LSR II flow cytometer. A computer system (CellQuest Pro, Becton Dickinson) was used for data acquisition and analysis. Data for 20.000 events were stored. A cell gate containing BEAS-2B cells was established on the basis of forwarding and side light scatter. Four different populations of cells were detected with the Annexin V-FITC kit: normal cells that were Annexin negative and PI negative and express no fluorescence, early apoptotic cells that were Annexin positive and PI negative and express green fluorescence, late apoptotic/necrotic cells that were Annexin positive and PI positive and express green and orange fluorescence, and necrotic cells that were Annexin negative and PI positive and express orange fluorescence. All samples were measured in three independent experiments.

The human lung normal BEAS-2B cell line was selected for assessing cell metabolic activity in the presence of $\left[\mathrm{Ni}(\mathrm{iaa})_{2}\left(\mathrm{H}_{2} \mathrm{O}\right)_{2}\right] \cdot \mathrm{H}_{2} \mathrm{O}$ complex and its components using the MTT test. The exponentially growing cells $\left(1 \times 10^{5} / \mathrm{mL}\right)$ were treated with nickel complex $\left[\mathrm{Ni}(\mathrm{iaa})_{2}\left(\mathrm{H}_{2} \mathrm{O}\right)_{2}\right] \cdot \mathrm{H}_{2} \mathrm{O}$ or nickel alone or ligand alone at the range of concentrations $7-250 \mu \mathrm{M}$ for $48 \mathrm{~h}$. Analysis of cell metabolic activity was carried out according to manufacturer instructions using EZcount MTT Cell Assay kit (HiMedia, India). The amount of formazan was determined by measuring the absorbance at $570 \mathrm{~nm}$ and $660 \mathrm{~nm}$ using Microplate Reader TECAN Infinite 200 PRO (Tecan Group Ltd., Switzerland). Per cent cell metabolic activity was calculated as cell metabolic activity of the experimental samples/cell metabolic activity of the control samples $\times 100$. All samples were measured in three independent experiments.

\subsection{Antimicrobial properties of \\ [Ni(iaa $\left.)_{2}\left(\mathrm{H}_{2} \mathrm{O}\right)_{2}\right] \cdot \mathrm{H}_{2} \mathrm{O}$ and its components}

The $\sim 2 \times 10^{5} \mathrm{cfu} / \mathrm{ml}$ E. coli ATCC 8739, S. aureus ATCC 6538P, P. aeruginosa ATCC 15692 PAO1 bacterial cells and Candida albicans ATTC 10231 and SC5314 strains fungal cells were grown in Tryptic Soy Broth and Sabouraud Broth (Oxoid, USA). The microbes were cultivated in the presence of $\left[\mathrm{Ni}(\mathrm{iaa})_{2}\left(\mathrm{H}_{2} \mathrm{O}\right)_{2}\right] \cdot \mathrm{H}_{2} \mathrm{O}$ at a non-cytotoxic concentration $(125 \mu \mathrm{M})$ for $24 \mathrm{~h}$ at $37^{\circ} \mathrm{C}$ with $5 \% \mathrm{CO}_{2}$ in stationary culture. Bacterial viability was expressed in terms of colony-forming units $(\mathrm{CFU} / \mathrm{ml})$ by the cultivation method in TSB-agar or Sabouraud-agar growth medium. All samples were measured in three independent experiments.

\section{Results and Discussion}

\section{$\left.3.1\left[\mathrm{Ni}(\mathrm{iaa})_{2}\left(\mathrm{H}_{2} \mathrm{O}\right)_{2}\right] \cdot \mathrm{H}_{2} \mathrm{O}\right]$ structure description}

As a result of the reaction in the aqueous solution of nickel(II) cation with an anion of imidazole-4-acetate (iaa), a coordination compound was created, which is described by the following formula: [Ni(iaa $\left.)_{2}\left(\mathrm{H}_{2} \mathrm{O}\right)_{2}\right]$. $\mathrm{H}_{2} \mathrm{O}$ (Figure 1). Two imidazole-4-acetate anions and two molecules of water are connected with central nickel(II) ion. Both imidazole ligands, as well as water ones, are arranged in cis position in respect of each other. The anion of imidazole-4-acetic acid is a chelating ligand. Azomethine nitrogen atoms of imidazole rings and carboxylate oxygen atoms are donor atoms.

The lengths of nickel-nitrogen bonds are 2.028(l) and 2.045(l) $\AA$, respectively. The lengths of bonds of a central nickel(II) ion with oxygen atoms of carboxyl groups $\mathrm{Ni}-\mathrm{O}(11)$ and $\mathrm{Ni}-\mathrm{O}(21)$ are slightly longer and are 2.086(1) and 2.103(1) A, respectively (Table 2).

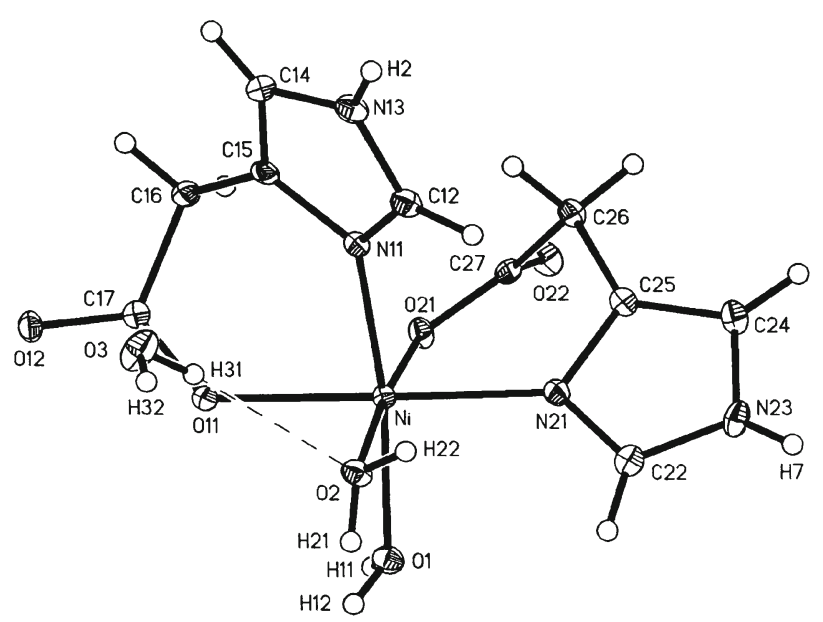

Figure 1. The structure and numbering scheme of $\left[\mathrm{Ni}(\mathrm{iaa})_{2}\left(\mathrm{H}_{2} \mathrm{O}\right)_{2}\right] \cdot \mathrm{H}_{2} \mathrm{O}$. 
Table 2. Selected bond lengths $[\AA]$ and angles [deg] for $\left[\mathrm{Ni}(\mathrm{iaa})_{2}\left(\mathrm{H}_{2} \mathrm{O}\right)_{2}\right] \mathrm{H}_{2} \mathrm{O}$.

\begin{tabular}{lc}
\hline Bond lengths & {$[\AA]$} \\
\hline $\mathrm{Ni}-\mathrm{N}(21)$ & $2.028(1)$ \\
$\mathrm{Ni}-\mathrm{N}(11)$ & $2.044(1)$ \\
$\mathrm{Ni}-\mathrm{O}(21)$ & $2.086(1)$ \\
$\mathrm{Ni}-\mathrm{O}(11)$ & $2.103(1)$ \\
$\mathrm{Ni}-\mathrm{O}(1)$ & $2.058(1)$ \\
$\mathrm{Ni}-\mathrm{O}(2)$ & $2.149(1)$ \\
\hline $\mathrm{Bond}$ angles & {$[\mathrm{deg}]$} \\
\hline $\mathrm{N}(21)-\mathrm{Ni}-\mathrm{N}(11)$ & $93.18(6)$ \\
$\mathrm{N}(21)-\mathrm{Ni}-\mathrm{O}(1)$ & $93.71(6)$ \\
$\mathrm{N}(11)-\mathrm{Ni}-\mathrm{O}(1)$ & $170.96(6)$ \\
$\mathrm{N}(21)-\mathrm{Ni}-\mathrm{O}(21)$ & $86.05(5)$ \\
$\mathrm{N}(11)-\mathrm{Ni}-\mathrm{O}(21)$ & $97.90(5)$ \\
$\mathrm{O}(1)-\mathrm{Ni}-\mathrm{O}(21)$ & $88.42(5)$ \\
$\mathrm{N}(21)-\mathrm{Ni}-\mathrm{O}(11)$ & $178.88(5)$ \\
$\mathrm{N}(11)-\mathrm{Ni}-\mathrm{O}(11)$ & $86.13(5)$ \\
$\mathrm{O}(1)-\mathrm{Ni}-\mathrm{O}(11)$ & $87.08(5)$ \\
$\mathrm{O}(21)-\mathrm{Ni}-\mathrm{O}(11)$ & $93.17(5)$ \\
$\mathrm{N}(21)-\mathrm{Ni}-\mathrm{O}(2)$ & $90.71(6)$ \\
$\mathrm{N}(11)-\mathrm{Ni}-\mathrm{O}(2)$ & $85.72(6)$ \\
$\mathrm{O}(1)-\mathrm{Ni}-\mathrm{O}(2)$ & $88.34(6)$ \\
$\mathrm{O}(21)-\mathrm{Ni}-\mathrm{O}(2)$ & $175.26(5)$ \\
$\mathrm{O}(11)-\mathrm{Ni}-\mathrm{O}(2)$ & $90.12(5)$ \\
\hline
\end{tabular}

Apart from two anions of the azole ligand, there are two molecules of water in the coordination sphere of the nickel(II) ion. Bond lengths of an oxygen atom of water molecules with a nickel(II) ion are: $\mathrm{Ni}-\mathrm{O}(1)$ 2.058(1) and Ni - O(2) 2.149(1) A. Two nitrogen atoms, as well as four atoms of oxygen, are in direct proximity of a nickel(II) cation (chromophore $\mathrm{NiO}_{4} \mathrm{~N}_{2}$ ). These atoms determine the hexacoordinate surrounding of the central ion with a distorted octahedron geometry. The distortion of a coordination octahedral polyhedron is mainly caused by the chelating character of the imidazole ligand. It refers to the above-mentioned bond lengths as well as the angles formed by these bonds. Bond angles of nitrogen and oxygen donor atoms of the imidazole ligand with nickel(II) atom, namely $\mathrm{O}(11)-\mathrm{Ni}-\mathrm{N}(11)$ and $\mathrm{O}(21)-\mathrm{Ni}-\mathrm{N}(21)$ are 86.13(5) and $86.05(5)^{\circ}$, respectively. On the other hand, the angles of nitrogen-nickel-nitrogen and $\mathrm{O}(11)-\mathrm{Ni}-\mathrm{O}(21)$ bonds differ from the right angle, which is appropriate for an ideal octahedron, by about $3.2^{\circ}$.

In the complex molecule, $\left[\mathrm{Ni}(\mathrm{iaa})_{2}\left(\mathrm{H}_{2} \mathrm{O}\right)_{2}\right] \cdot \mathrm{H}_{2} \mathrm{O}$, there is a third water molecule situated beyond the coordination sphere of the central ion. A hydrogen atom of this molecule $(\mathrm{H}(31))$ creates bifurcated, intramolecular bonds, with an oxygen atom $\mathrm{O}(11)$ of the $\mathrm{COO}^{-}$ group on one side and with an oxygen atom $\mathrm{O}(2)$ of the coordinately bound water molecule on the other. The lengths of these bonds are $\mathrm{H}(31)$... $\mathrm{O}(11), 2.66(3) \AA$ and $\mathrm{H}(31)$... O(2), 2.24(3) A (Table 3).

Imidazole-4(5)-acetate anion in a water solution is present in two tautomeric forms connected with regrouping of the pyrrolic hydrogen atom between positions 1 and 3 of the imidazole ring. The presented X-ray structural examination explicitly proves that in the reaction of metal ions, a tautomer with the acetic functional group in direct proximity of the donor nitrogen atom is privileged, i.e., an imidazole-4-acetate anion. As a result of coordination with the $\mathrm{Ni}$ (II) ion, stable six-membered chelatic rings are formed.

\subsection{Spectroscopic and magnetic properties of [Ni(iaa $\left.)_{2}\left(\mathrm{H}_{2} \mathrm{O}\right)_{2}\right] \cdot \mathrm{H}_{2} \mathrm{O}$ complex}

3.2a Infrared spectra: Infrared and far-infrared spectra (IR and far IR) confirmed the presence of the imidazole-4-acetate anion as well as water molecules in the analyzed nickel(II) complex. The donor type of the carboxyl group in complexes is determined by the difference in the positioning of asymmetric and symmetric stretching of vibrational bands $\left(\nu_{\text {as }}\right.$ and $v_{s}$, respectively). ${ }^{16}$ For the examined complex, these bands are placed at $\nu_{\mathrm{as}}=1580$ and $v_{\mathrm{s}}=1404 \mathrm{~cm}^{-1}$. From the presented structure of the $\left[\mathrm{Ni}(4-\mathrm{iaa})_{2}\left(\mathrm{H}_{2} \mathrm{O}\right)_{2}\right] \cdot \mathrm{H}_{2} \mathrm{O}$ complex, it clearly appears that the carboxylate group in the nickel(II) ion bonding is a donor of one electron pair. However, the parameter $\Delta=v_{\mathrm{as}}-v_{\mathrm{s}}=176 \mathrm{~cm}^{-1}$ is not typical of this type of coordination, which corresponds to the bridging character of coordinating the $\mathrm{COO}^{-}$group. ${ }^{16}$ The difference in spectra pictures is explained by the additional (apart from the coordinate bond with the nickel ion) participation of oxygen atoms of the $\mathrm{COO}^{-}$group in hydrogen bonds (Table 3). As a result of this interaction, the carboxyl group has the features of the "pseudo-bridging" ligand. ${ }^{17}$

The presence of water molecules and hydrogen bonds in the X-ray analysis confirms a broad and complex band in the range of $2700-3600 \mathrm{~cm}^{-1}$. In addition, a mediumintensity bending vibrational band $\mathrm{HOH}$ placed at $1650 \mathrm{~cm}^{-1}$.

3.2b $\quad d-d$ spectra: $\quad$ There were three absorption bands in the visible area, as well as in near-infrared, characteristic of hexacoordinate and octahedral nickel(II) complexes. Low-energy absorption observed as a broadband at $9450 \mathrm{~cm}^{-1}$ corresponds to electronic transition ${ }^{3} \mathrm{~A}_{2 \mathrm{~g}}(\mathrm{~F}) \rightarrow{ }^{3} \mathrm{~T}_{2 \mathrm{~g}}(\mathrm{~F})\left(v_{1}\right)$. Another two bands at $16040 \mathrm{~cm}^{-1}$ and $26740 \mathrm{~cm}^{-1}$ are connected with 
Table 3. Hydrogen-bonds for $\left[\mathrm{Ni}(\mathrm{iaa})_{2}\left(\mathrm{H}_{2} \mathrm{O}\right)_{2}\right] \mathrm{H}_{2} \mathrm{O}\left[\AA\right.$ and $\left.^{\circ}\right]$.

\begin{tabular}{lcccc}
\hline D-H..A & d(D-H) & d(H..A) & d(D...A) & $<($ DHA) \\
\hline $\mathrm{N}(13)-\mathrm{H}(2) \ldots \mathrm{O}(3) \mathrm{a}$ & $0.85(2)$ & $2.08(2)$ & $2.886(2)$ & $158(2)$ \\
$\mathrm{O}(3)-\mathrm{H}(31) \ldots \mathrm{O}(2)$ & $0.82(3)$ & $2.24(3)$ & $3.006(2)$ & $156(3)$ \\
$\mathrm{O}(3)-\mathrm{H}(31) \ldots \mathrm{O}(11)$ & $0.82(3)$ & $2.66(3)$ & $3.214(2)$ & $127(3)$ \\
\hline
\end{tabular}

Symmetry transformations used to generate equivalent atoms: $\mathrm{a}=-\mathrm{x}, \mathrm{y}+1 / 2,-\mathrm{z}+1 / 2$.

the following transitions: ${ }^{3} \mathrm{~A}_{2 \mathrm{~g}}(\mathrm{~F}) \rightarrow{ }^{3} \mathrm{~T}_{\mathrm{gg}}(\mathrm{F})\left(\nu_{2}\right)$ and ${ }^{3} \mathrm{~A}_{2 \mathrm{~g}}(\mathrm{~F}) \rightarrow{ }^{3} \mathrm{~T}_{1 \mathrm{~g}}(\mathrm{P})\left(\nu_{3}\right)$, respectively. ${ }^{18}$

3.2c Magnetic moment: The effective magnetic moment of $\left[\mathrm{Ni}(\mathrm{iaa})_{2}\left(\mathrm{H}_{2} \mathrm{O}\right)_{2}\right] \cdot \mathrm{H}_{2} \mathrm{O}\left(\mu_{\text {eff }}=2.80\right.$ B.M. $)$ determined at room temperature, corresponding to two unpaired electrons $\left(\mathrm{d}^{8}\right)$ was found to be very close to the spin-only value expected for the hexacoordinate octahedral geometry of the nickel(II) environment. ${ }^{18}$

\section{3 [Ni( iaa $\left.)_{2}\left(\mathrm{H}_{2} \mathrm{O}\right)_{2}\right] \cdot \mathrm{H}_{2} \mathrm{O}$ binding to DNA}

The electronic spectra are the most common way to investigate the interaction of complexes with DNA. When the complexes intercalate with the base pairs of DNA, the $\pi^{*}$ orbitals of the intercalated complexes can couple with the $\pi$ orbitals of the base pairs, thus decreasing the $\pi-\pi^{*}$ transition energies. At the same time, the coupling $\pi^{*}$ orbitals are partially filled by electrons, thus decreasing the transition probabilities. Therefore, intercalative interaction can result in both hypochromism and redshift.

The absorption spectra of the $\left[\mathrm{Ni}(\mathrm{iaa})_{2}\left(\mathrm{H}_{2} \mathrm{O}\right)_{2}\right] \cdot \mathrm{H}_{2} \mathrm{O}$ complex in the absence and presence of DNA are given in Figure S1A, in Supplementary Information. The band at $215 \mathrm{~nm}$, in the spectrum of nickel(II) complex, is attributed to intraligand $\pi-\pi *$ transition. Along with the increase of DNA concentration, a hypochromism and a slight red shift (bathochromism) can be observed (about $1 \mathrm{~nm}$ ). The hypochromism in the band at $215 \mathrm{~nm}$ reaches 15.4 , for $\left[\mathrm{Ni}(\mathrm{iaa})_{2}\left(\mathrm{H}_{2} \mathrm{O}\right)_{2}\right] \cdot \mathrm{H}_{2} \mathrm{O}$. This spectral characteristics obviously suggest that $\left[\mathrm{Ni}(\mathrm{iaa})_{2}\left(\mathrm{H}_{2} \mathrm{O}\right)_{2}\right] \cdot \mathrm{H}_{2} \mathrm{O}$ interacts with DNA most likely through a mode that involves a stacking interaction between the aromatic imidazole chromophore and the base pairs of DNA. In order to explain the binding strength of nickel(II) complex, the intrinsic binding constants $\mathrm{K}_{\mathrm{b}}$ were calculated by tracking absorbance spectra. The $\mathrm{K}_{\mathrm{b}}$ constants for [Ni(iaa $\left.)_{2}\left(\mathrm{H}_{2} \mathrm{O}\right)_{2}\right] \cdot \mathrm{H}_{2} \mathrm{O}$ is $3.0 \times 10^{4} \mathrm{M}^{-1}$. It is two or three orders of magnitude less than those observed for typical classical intercalators, whose binding constants are on the order of $10^{6}-10^{7} \mathrm{M}^{-1} \cdot{ }^{19}$
To further investigate the affinity of the $\left[\mathrm{Ni}(\mathrm{iaa})_{2}\right.$ $\left.\left(\mathrm{H}_{2} \mathrm{O}\right)_{2}\right] \cdot \mathrm{H}_{2} \mathrm{O}$ complex for DNA competitive binding, experiments with ethidium bromide (EB) were carried out. EB is a weakly fluorescent compound, but in the presence of DNA its emission intensity is greatly enhanced, because of its strong intercalation between the adjacent DNA base pairs. ${ }^{20}$ Displacement of EB from its EB-DNA complex due to gradual titration by competing intercalator results in subsequent quenching of its emission band. ${ }^{21}$ Such an effect was observed on fluorescent spectrum of the examined compound (Figure S1B, Supplementary Information). Upon addition of the nickel(II) complex, the emission intensity of EB-bound DNA solution decreased. It indicates that $\left[\mathrm{Ni}(\mathrm{iaa})_{2}\left(\mathrm{H}_{2} \mathrm{O}\right)_{2}\right] \cdot \mathrm{H}_{2} \mathrm{O}$ complex interacts with DNA because $\mathrm{EB}$ molecules were gradually released from its EB-DNA complex in the presence of tested nickel(II) complex. ${ }^{22}$ The quenching efficiency of complexes was evaluated from the Stern-Volmer constant $\mathrm{K}_{\mathrm{SV}}$. The quenching plots of $\mathrm{I}_{0} / \mathrm{I} v \mathrm{~s}$. [complex] were consistent with the linear Stern-Volmer equation. The $\mathrm{K}_{\mathrm{Sv}}$ values were $1 \times 10^{4} \mathrm{M}^{-1}$ for $\left[\mathrm{Ni}(\mathrm{iaa})_{2}\left(\mathrm{H}_{2} \mathrm{O}\right)_{2}\right] \cdot \mathrm{H}_{2} \mathrm{O}$ complex.

High Resolution Melting (HRM) analysis is a postPCR analysis method used to identify variations in nucleic acid sequences: single nucleotide polymorphism genotyping, DNA methylation analysis, DNA mapping, mutation scanning and species identification. ${ }^{23-25}$ In this study, the new application of this technique was proposed to the analysis of interactions of metal ions and their complexes with DNA. Figure S2, Supplementary Information shows that $\mathrm{NiCl}_{2}$ at $500 \mu \mathrm{M}$ results in a significant reduction in the peak of fluorescence associated with releasing of SYBR Green I molecules from fragmented DNA (strand breaks) at a lower temperature in comparison to untreated control. The releasing of more fluorescence dye molecules from fragmented DNA by $\mathrm{NiCl}_{2}$ at lower temperature than for control was correlated with the amount of $\mathrm{H}$-bonds (length of DNA). The results presented that interaction of $\left[\mathrm{Ni}(\mathrm{iaa})_{2}\left(\mathrm{H}_{2} \mathrm{O}\right)_{2}\right] \cdot \mathrm{H}_{2} \mathrm{O}$ complex at $125 \mu \mathrm{M}$ and $500 \mu \mathrm{M}$ is weaker with DNA than nickel(II) ions because only the lower peak on DNA melting curve was observed in comparison to control (Figure S3, Supplementary 
Information). [Ni(iaa $\left.)_{2}\left(\mathrm{H}_{2} \mathrm{O}\right)_{2}\right] \cdot \mathrm{H}_{2} \mathrm{O}$ displaced the SYBR Green I which was intercalated in the minor groove of DNA. This effect confirmed the results obtained by the absorption spectral studies and competitive binding fluorescence measurements.

In this study, the novel application of PCR-HRM method was presented as a useful tool in the analysis of interactions of metal ions and their complexes with DNA. Metal ions are able to physically destabilize the DNA duplex, what might be indicated on the DNA spectra obtained in melting analysis. The melting temperature depends on both the length of DNA and the specific nucleotide sequence composition of that molecule. It seems very promising to use this technique in the analysis of interactions of specific genes with different chemical agents. The structure and nucleotide composition of tested gene region might be planned and various types of its damages might be determined in the same experiment using PCR-HRM studies. The results interpretation is based on the specific changes of the level of SYBR Green I dye fluorescence in function of temperature, observed on the melting curve in the PCR-HRM method. Amplicon with intercalated dye is incubated with a testing agent and heated gradually from around $50{ }^{\circ} \mathrm{C}$ up to around $95{ }^{\circ} \mathrm{C}$. As the temperature increases, the melting temperature of the amplicon is reached. The value of temperature is specific to the length and nucleotide composition of the amplicon. Next, SYBR Green I dye is released from the amplicon complex with DNA and fluorescence fades away. The chemical agents might interact with DNA and change the melting temperature of the amplicon in comparison to non-treated control via inducing DNA strand breaks, binding with DNA or forming cross-links, displacing SYBR Green I dye. Hence, these interactions observed as melting curves, allow to determine the specific DNA-metal reaction.

\section{$\left.3.4 \mathrm{Ni}(\mathrm{iaa})_{2}\left(\mathrm{H}_{2} \mathrm{O}\right)_{2}\right] \cdot \mathrm{H}_{2} \mathrm{O}$ interactions with protein}

Bovine serum albumin (BSA) was chosen as a model protein with well-known structure and possessing two tryptophan residue Trp-134 and Trp-212, located respectively in domains I and II. The trp-212 residue is surrounded by a hydrophobic environment within a protein pocket while Trp-134 residue is located in a hydrophilic environment, close to the protein surface. The changes in fluorescence intensity of tryptophan suggest an environment changes on protein surfaces. BSA as albumin is a good example of transporting protein. The interaction between nickel complex and albumin seems to be crucial. Experimental data showed that the quenching process had a dynamic nature at a complex concentration up to $60 \mu \mathrm{M}$ of $\left[\mathrm{Ni}(\mathrm{iaa})_{2}\right.$ $\left.\left(\mathrm{H}_{2} \mathrm{O}\right)_{2}\right] \mathrm{H}_{2} \mathrm{O}$ (Figure $\mathrm{S} 4$, Supplementary Information). The intensity of fluorescence of BSA above this concentration was constant for this compound. The quenching process was described by the Stern-Volmer equation: $\mathrm{F} 0 / \mathrm{F}=1+\mathrm{Ksv}[\mathrm{Q}]$, where $\mathrm{Q}$ is a concentration of quencher and Ksv is a Stern-Volmer constant, which describe the strength of quenching. The Ksv for $\left[\mathrm{Ni}(\mathrm{iaa})_{2}\left(\mathrm{H}_{2} \mathrm{O}\right)_{2}\right] \mathrm{H}_{2} \mathrm{O}$ is $1.1 \times 10^{5} \mathrm{M}^{-1}$.

The saturation complex to protein could be also described by a number of compounds attached to protein surface (n). The number of compounds interacting with BSA did not depend on the size of complexes. For $\left[\mathrm{Ni}(\mathrm{iaa})_{2}\left(\mathrm{H}_{2} \mathrm{O}\right)_{2}\right] \mathrm{H}_{2} \mathrm{O}$, the number of molecules attached to BSA was equal to 0.5. It indicates that for one $\left[\mathrm{Ni}(\mathrm{iaa})_{2}\left(\mathrm{H}_{2} \mathrm{O}\right)_{2}\right] \mathrm{H}_{2} \mathrm{O}$ complex, two molecules of BSA were required.

\subsection{Cytotoxicity of $\left[\mathrm{Ni}(\mathrm{iaa})_{2}\left(\mathrm{H}_{2} \mathrm{O}\right)_{2}\right] \cdot \mathrm{H}_{2} \mathrm{O}$}

Table S5 (Supplementary Information) presents the percentage of apoptotic and necrotic BEAS-2B cells following treatment with $\left[\mathrm{Ni}(\mathrm{iaa})_{2}\left(\mathrm{H}_{2} \mathrm{O}\right)_{2}\right] \cdot \mathrm{H}_{2} \mathrm{O}$ or metal alone or free ligand alone in range of concentrations from 30 to $500 \mu \mathrm{M}$. The nickel complex with imidazole-4-acetic acid and metal ion alone at concentration $500 \mu \mathrm{M}$ induced late apoptosis and necrosis in BEAS-2B cells after $48 \mathrm{~h}$ treatment in contrast to free ligand. Figure S6 (Supplementary Information) shows the metabolic activity of BEAS-2B cells after $48 \mathrm{~h}$ treatment with $\left[\mathrm{Ni}(\mathrm{iaa})_{2}\left(\mathrm{H}_{2} \mathrm{O}\right)_{2}\right] \cdot \mathrm{H}_{2} \mathrm{O}$ complex or metal alone or free ligand alone in range of concentrations from 7 to $250 \mu \mathrm{M}$. The nickel complex and metal ion alone decreased metabolic activity of BEAS$2 \mathrm{~B}$ cells at $250 \mu \mathrm{M}$ in contrast to free ligand.

The newly synthesized $\left[\mathrm{Ni}(\mathrm{iaa})_{2}\left(\mathrm{H}_{2} \mathrm{O}\right)_{2}\right] \cdot \mathrm{H}_{2} \mathrm{O}$ possesses similar cytotoxic/proapoptotic activities as metals ions alone but presents weaker interaction with DNA. Additionally, the biophysical studies revealed that $\left[\mathrm{Ni}(\mathrm{iaa})_{2}\left(\mathrm{H}_{2} \mathrm{O}\right)_{2}\right] \cdot \mathrm{H}_{2} \mathrm{O}$ interacts relatively strongly with proteins $\left(\mathrm{Ksv}=1.1 \times 10^{5} \mathrm{M}^{-1}\right.$ for BSA as a model potein). ${ }^{25}$ It indicates that the mechanism of $\left[\mathrm{Ni}(\mathrm{iaa})_{2}\left(\mathrm{H}_{2} \mathrm{O}\right)_{2}\right] \cdot \mathrm{H}_{2} \mathrm{O}$ action in eukaryotic cells might be rather associated with proteins activity disruption than direct DNA damage. $\left[\mathrm{Ni}(\mathrm{iaa})_{2}\left(\mathrm{H}_{2} \mathrm{O}\right)_{2}\right] \cdot \mathrm{H}_{2} \mathrm{O}$ might interfere with cell cycle regulation, transcription or DNA repair process.

\subsection{Antimicrobial properties of \\ [Ni(iaa $\left.)_{2}\left(\mathrm{H}_{2} \mathrm{O}\right)_{2}\right] \cdot \mathrm{H}_{2} \mathrm{O}$}

Table S7 (Supplementary Information) shows the antimicrobial effect of $\left[\mathrm{Ni}(\mathrm{iaa})_{2}\left(\mathrm{H}_{2} \mathrm{O}\right)_{2}\right] \cdot \mathrm{H}_{2} \mathrm{O}$ at a non-cytotoxic concentration $(125 \mu \mathrm{M})$ against bacterial 
E. coli, S. aureus, P. aeruginosa and two fungal Candida albicans strains. The non-cytotoxic concentration was selected on the basis of the results for BEAS-2B cells and our previous study. ${ }^{26}$ Generally, the nickel complex had very weak antibacterial properties in contrast to antifungal activity. [ $\left.\mathrm{Ni}(\mathrm{iaa})_{2}\left(\mathrm{H}_{2} \mathrm{O}\right)_{2}\right] \cdot \mathrm{H}_{2} \mathrm{O}$ reduced at $99 \%$ the number of fungal cells of both strains $(\mathrm{cfu} / \mathrm{mL})$ in comparison to non-treated control.

Candida albicans is the most prevalent human pathogen colonizing the skin, mouth, gastrointestinal tract, and female reproductive tract. In candidemia treatment three types of drugs are used: azoles (1,3imidazole and 1,2,4-triazole derivatives), amphotericin $\mathrm{B}$, and echinocandins, which are able to block biosynthesis of ergosterol, to remove ergosterol from fungal plasma membranes and to inhibit $(1 \rightarrow 3) \beta$-D-glucan synthase, respectively. ${ }^{27}\left[\mathrm{Ni}(\mathrm{iaa})_{2}\left(\mathrm{H}_{2} \mathrm{O}\right)_{2}\right] \cdot \mathrm{H}_{2} \mathrm{O}$ complex, belonging to azoles, might inhibit fungal sterol $14 \alpha$-demethylase which removes the $14 \alpha$-methyl group from the lanosterol during ergosterol biosynthesis. ${ }^{28}$

\section{Conclusions}

In conclusion, [ $\left.\mathrm{Ni}(\mathrm{iaa})_{2}\left(\mathrm{H}_{2} \mathrm{O}\right)_{2}\right] \cdot \mathrm{H}_{2} \mathrm{O}$ complex was synthesized and characterized in this study. [Ni(iaa) $)_{2}$ $\left.\left(\mathrm{H}_{2} \mathrm{O}\right)_{2}\right] \cdot \mathrm{H}_{2} \mathrm{O}$ possesses antifungal activity at noncytotoxic concentrations against human normal BEAS2B cells, which is relevant from the clinical point of view. [ $\left.\mathrm{Ni}(\mathrm{iaa})_{2}\left(\mathrm{H}_{2} \mathrm{O}\right)_{2}\right] \cdot \mathrm{H}_{2} \mathrm{O}$ possesses clinical potential as measured by standard techniques as well as, for the first time, tested for use in the PCR-HRM method.

\section{Supplementary Information (SI)}

Crystallographic data for [Ni(iaa $\left.)_{2}\left(\mathrm{H}_{2} \mathrm{O}\right)_{2}\right] \cdot \mathrm{H}_{2} \mathrm{O}$ have been deposited with the Cambridge Crystallographic Data Center, CCDC No. 213350. Supplementary Information is available at www.ias.ac.in/chemsci.

\section{Acknowledgements}

This work was supported by the Ministry of Science and Higher Education Poland BS UJK 2017 No. 612458 (chemical part) and No. 612087 (biological part).

\section{References}

1. Wang Y F, Shyu H W, Chang Y C, Tseng W C, Huang Y L, Lin K H, Chou M C, Liu H L and Chen C Y 2012 Nickel (II)-induced cytotoxicity and apoptosis in human proximal tubule cells through a ROS- and mitochondriamediated pathway Toxicol. Appl. Pharmacol. 259177
2. Vamsikrishna N, Kumar M P, Ramesh G, Ganjiet N, Daravathal S and Shivaraj 2017 DNA interactions and biocidal activity of metal complexes of benzothiazole Schiff bases: Synthesis, characterization and validation J. Chem. Sci. 129609

3. Shakir M, Bano N, Rauf M A and Owaiset M 2017 Pharmacologically significant tetraaza macrocyclic metal complexes derived from isatin and 3,4diaminobenzophenone: Synthesis, spectral studies and comparative in vitro biological assessment J. Chem. Sci. 1291905

4. Sudeepa K, Narsimha N, Aparna B, Sreekanthet S, Aparna A V, Ravi M, Mohmed J and Sarala Devi C H 2018 Synthesis, spectral characterization, antimicrobial, DNA interactions and molecular modeling studies of metal complexes of 1,3-benzothiazole carbohydrazone J. Chem. Sci. 13052

5. Woźniak K and Błasiak J 2002 Free radicals-mediated induction of oxidized DNA bases and DNA-Protein cross-links by nickel chloride Mutat. Res. 514233

6. Blasiak J, Arabski M, Pertyński T, Malecka-Panas E, Woźniak K and Drzewoski J 2002 DNA damage in human colonic mucosa cells evoked by nickel and protective action of quercetin-Involvement of free radicals? Cell Biol. Toxicol. 18279

7. Chen C Y, Wang Y F, Huang W R and Huang Y T 2003 Nickel induces oxidative stress and genotoxicity in human lymphocytes Toxicol. Appl. Pharmacol. 189 153

8. Sheldrick G M 1997 SHELX 97, Program for Solution of Crystal Structures. University of Göttingen, Germany

9. Sheldrick G M 1997 SHELXL 97, Program for Crystal Structure Refinement. University of Göttingen, Germany

10. Marmur J 1961 A procedure for the isolation of deoxyribonucleic acid from micro-organisms J. Mol. Biol. 3208

11. Reichmann M E, Rice S A, Thomas C A and Doty P 1954 A further examination of the molecular weight and size of desoxypentose nucleic acid J. Am. Chem. Soc. 76 3047

12. Wolfe A, Shimer G H and Meehan T 1987 Polycyclic aromatic hydrocarbons physically intercalate into duplex regions of denatured DNA Biochemistry 266392

13. Schmechel D E V and Crothers D M 1971 Kinetic and hydrodynamic studies of the complex of proflavine with poly A poly U Biopolymers $\mathbf{1 0} 465$

14. Lakowicz J R and Weber G 1973 Quenching of fluorescence by oxygen. A probe for structural fluctuations in macromolecules Biochemistry 124161

15. Lakowicz J R 2006 In Principles of Fluorescency Spectroscopy $3^{\text {rd }}$ edn. (New York: Springer)

16. Nakamoto K 1986 In Infrared and Raman Spectra of Inorganic and Coordination Compounds $5^{\text {th }}$ edn. (New York: Wiley)

17. Kurdziel K, Głowiak T, Materazzi and Jezierska J 2003 Crystal structure and physicochemical properties of cobalt(II) and manganese(II) with imidazole-acetate anion Polyhedron 223123

18. Lever B 1984 In Inorganic Electronic Spectroscopy $2^{\text {nd }}$ edn. (Amsterdam, New York, Tokyo: Elsevier)

19. Cory M, McKee D D, Kagan J, Henry D W and Miller J A 1985 Design, synthesis, and DNA binding properties of bifunctional intercalators. Comparison of 
polymethylene and diphenyl ether chains connecting phenanthridine J. Am. Chem. Soc. 1072528

20. Olmsted J and Kearns D R 1977 Mechanism of ethidium bromide fluorescence enhancement on binding to nucleic acids Biochemistry 163647

21. Baguley B C and Bret M Le 1984 Quenching of DNAethidium fluorescence by amsacrine and other antitumor agents: A possible electron-transfer effect Biochemistry 23937

22. Novakova O, Chen H, Vrana O, Rodger A, Sadler P J and Brabec V 2003 DNA interactions of monofunctional organometallic ruthenium(II) antitumor complexes in cell-free media Biochemistry 4211544

23. Matsuda K 2017 PCR-based detection methods for single-nucleotide polymorphism or mutation: Real-Time PCR and its substantial contribution toward technological refinement Adv. Clin. Chem. 8045

24. Berenstein R 2015 Class III Receptor Tyrosine Kinases in Acute Leukemia - Biological Functions and Modern Laboratory Analysis Biomark Insights 101
25. Hoseinpour F, Foroughi A, Nomanpour B and Nasab R S 2017 Identification and differentiation of Campylobacter species by high-resolution melting curve analysis Microb. Pathog. 108109

26. Topală T, Bodoki A, Oprean L and Oprean R 2014 Bovine serum albumin interactions with metal complexes Clujul Med. 87215

27. Gałczyńska K, Kurdziel K, Adamus-Białek W, Wąsik S, Szary K, Drabik M, Węgierek-Ciuk A, Lankoff A and Arabski M 2015 The effects of nickel (II) complexes with imidazole derivatives on pyocyanin and pyoverdine production by Pseudomonas aeruginosa strains isolated from cystic fibrosis Acta Biochim. Pol. 62739

28. Hargrove T Y, Friggeri L, Wawrzak Z, Qi A, Hoekstra W J, Schotzinger R J, York J D, Peter Guengerich F and Lepesheva G I 2017 Structural analyses of Candida albicans sterol $14 \alpha$-demethylase complexed with azole drugs address the molecular basis of azole-mediated inhibition of fungal sterol biosynthesis J. Biol. Chem. 292 6728 